\title{
Mortality of young animals - the scale of the problem
}

\author{
J.-F. Grongnet ${ }^{1}$ and Christine Duvaux-Ponter ${ }^{2}$ \\ 'Ecole Nationale Supérieure Agronomique and INRA-Laboratoire du Jeune Ruminant \\ 65 Rue de Saint-Brieuc, 35042-Rennes Cedex, France \\ ${ }^{2}$ Institut National Agronomique Paris-Grignon \\ 16 Rue Claude Bernard, 75231 Paris Cedex 5, France
}

\section{ABSTRACT}

The mortality and morbidity of young production animals causes serious economic losses. This concerns both the developing countries as well as countries leading in modern animal production. The early postnatal period and weaning period are the most risky phases during the entire production process.

KEY WORKS: young animals, mortality

The mortality of young animals has an important effect on farm economy. Dardillat and Vallet (1984) have estimated the mortality of calves in France at about $10 \%$ during the first month post-partum. A quick calculation allows the losses linked to this figure to be calculated. In France, about 4 millions dairy calves and 3.7 millions beef calves are born each year. A reasonable estimation of the cost of each type of calf is 200 US $\$$ for the former and 500 US $\$$ for the latter (Fougères market, 1998). By using the above mentioned mortality rate of $10 \%$, the overall loss is estimeted as 265 millions US \$. The death of a calf is often the result of human negligence, perhaps of inattention can lasting only a few minutes. This cost of 200 US $\$$ represent the equivalent of the revenue of $600 \mathrm{~L}$ of milk, and therefore near $10 \%$ of the annual production of a good dairy cow. This quantity of milk is important and could only compensate the loss of a calf at the expense of considerable effort and not-negligible supplementary costs. For the beef calf, this comparison is not necessary because beef cow production is judged by the number of calves produced. When a calf dies, the farmer has to maintain the cow for a year during which it is unproductive. This loss can be considerable. 
Berthelon and Calavas (1987) conducted an economo-patholological survey of 92 sheep farms, in which they recorded a mortality rate of $10 \%$. A figure almost identical, 9.7\%, was reported by Green and Morgan (1993) in observations collected from well-run English farms. Therefore, using an estimated value of 60 US $\$$ (Berthelon and Calavas, 1987) for a new-born lamb, an overall loss of 50 million US $\$$ can be calculated in French rearing conditions. For goats, Morand-Fehr et al. (1982) the calculated the average mortality rate to be $12 \%$ before weaning in eight well-run experimental herds. For horses, French losses average $12 \%$ during early life, with a maximum of $17 \%$ for work-horse foals, born in extensive conditions, and $8 \%$ for thoroughbred foals, born in optimal conditions (Chavatte, INA-PG, personal communication).

Lastly, a survey conducted in 53 farms showed that the pig mortality rate averaged 19.2\% from birth to weaning (Quéméré et al., 1993) while technico-economic analyses performed by the Institut Technique du Porc (ITP), using results from 1994, established a mean rate of $17.6 \%$ (Dagorn, ITP, personal communication). By taking into account related figures, a conservative estimate of financial loss gives a figure of 200 million US \$/year.

After adding all the calculated figures for bovine, ovine and porcine species, without taking into account large mammals of minor economic importance, losses amounted to 500 million US \$. For numerous authors a $50 \%$ decrease in losses seems a reasonable goal to aim for. A figure of $100 \%$ is however totally unrealistic. The death of young animals, even when every effort is made to save them, will always be part of the landscape of animal breeding.

These losses are not of course limited to France but are universal. Only a few figures are available. Wikse et al. (1994) and Zaugg (1994) accept an average mortality rate of $10 \%$ for all American calves (USA). Between 1978 and 1985, Weller and Gianola (1989) recorded, in 100,000 Holstein Israeli heifers, a loss of $7.66 \%$ between 0 and $48 \mathrm{~h}$ after parturition. This figure is very close to the $7.8 \%$ calculated by Streit and Ernst (1992) from the study of 7,000 calvings in more than 200 Dutch cattle farms and to the figure of $8.73 \%$ established in Poland by Chmielnik and Sawa (1988) from 1810 calvings. Putting together all of the observations corresponding to the 90,000 calvings, taking place during 20 years among an American experimental herd of Hereford beef cows, Azzam et al. (1993) obtained a figure of $6.4 \%$ deaths, from birth to the end of the first week of life.

In developing countries, in which animal breeding frequently represents a very important economic sector, credible values are even more scarcely available. The indications are that the real figures are even more alarming and animals experience very rough rearing conditions, being left on their own. Indeed, in extensive conditions, kid mortality rate can be as high as $60 \%$ (O'Brien and Sherman, 1993). In France, however, in an outdoor herd of Lacaune ewes, where no farmer assistance was given, Lécrivain and Janeau (1988) recorded losses of $24 \%$ 
at 48 h during 4 consecutive years. Taking Brazil as an example, calf mortality rate, which is very high during the first month, is alone partly responsible for the low efficiency of cattle production (Gomes and Carneiro, 1977; Leite and Lima, 1983; Ribeiro et al., 1983) when compared to the situation in more developed countries. Among the threats that put the life of the new-born in danger the lack of acquired immunity and the resultant susceptibility to bacterial/viral infections is the most dramatic problem. It is something which occurs during the first hours of life but does not however lead to immediate death. The consequences occur later. Without defense against aggression, the morbidity of poorly protected animals is high and the mortality a month later will be greatly increased. The other dangers are related to the gastrointestinal tract immaturity associated with early weaning.

\section{REFERENCES}

Azzam S.M., Kinder J.E., Nielsen M.K., Werth L.A., Gregory K.E., Cundiff L.V., Koch R.M., 1993. Environmental effects on neonatal mortality of beef calves. J. Anim. Sci. 71, 282-290

Berthelon C., Calavas D., 1987. Mortalité néonatale: facteurs de risque. Pâtre, 347, 17-20

Chmielnik H., Sawa A., 1988. The reasons of perinatal period mortality of calves (in Polish). Zesz. probl. Post. Nauk rol. No. 333, 135-140

Dardillat C., Vallet A., 1984. Mesures d'hygiène et de ménagement et la période périnatale pour prévenir les maladies néonatales infectieuses des veaux. In: R. Jarrige (Editor). Physiologie et pathologie périnatales chez les animaux de ferme INRA, Paris, pp. 429-454

Gomes E.F.C., Carneiro J.M., 1977. Subsidios para a programaćčo do desenvolvimento da pecuária bovina mineira. Belo Horizonte, Imprensa Oficial, pp. 167

Green L.E., Morgan K.L., 1993. Mortality in early born, housed lambs in south-west England. Prev. Vet. Med. 17, 251-261

Lécrivain E., Janeau G., 1988. Mortalité néonatale d'agneaux nés en plein air sans l'aide de l'ćleveur. INRA Prod. Anim. 1 (5), 331-338

Leite R.C., Lima J.D., 1983. Fatores sanitários que influenciam na criaćčo de bezerros. Arq. Esc. Vet. UFMG, 34, 485-492

Morand-Fehr P., Villette Y., Guillimin P., Hervieu J., Faurie F., Mirman B., Broqua L., Brun-Bellut J., Toussaint G., 1982. Causes de mortalité des agneaux avant sevrage. In: L'agneau et le chevreau nouveau-né. INRA-ITOVIC, Paris

O'Brien J.P., Sherman D.M., 1993. Serum immunoglobulin concentrations of newborn goat kids and subsequent kid survival through weaning. Small Ruminant Res. 11, 71-77

Quéméré P., Cousin J., Flament J., Jacob B., Michel G., Poquet P., Richard S., Sibille J.L., 1993. Approche multifactorielle de la mortalité des porcelets de la naissance au sevrage. Journées Rech. Porcine 25, 113-122

Ribeiro M.F.B., Patarroyo J.H.S., Belem P.A.D., De Faria J.E., 1983. Hipogamaglobulinemia em bezerros. Arq. Bras. Med. Vet. Zoot 35, 537-546

Streit P., Ernst E., 1992. Influences des conditions d'élevage sur la mortalité péri- et postnatale de veaux. Zème communication: influcnce sur la mortalité postnatale de veaux. Züchtungskunde $64,35-44$

Weller J.I., Gianola D., 1989. Models for genetic analysis of dystocia and calf mortality. J. Dairy Sci. $72,2633-2643$ 
Wikse S.E., Kinsel M.L., Field R.W., Holland P.S., 1994. Investigating perinatal calf mortality in beef herds. Vet. clin. N. Amer.: Food Anim. Prod. 10 (1), 147-165

Zaugg J.L., 1994. Bovine plasma transfusions for sustained serum immunoglobulin concentrations in colostrum-deprived calves. Agri-practice 15 (8), 35-39 